\title{
A school-based body image intervention for young girls: is co-educational or single-sex delivery more effective?
}

\author{
Candice J Dunstan*, Susan J Paxton, Sian A McLean, Karen Gregg \\ From 2014 ANZAED Conference: Driven Bodies Driven Brains \\ Fremantle, Australia. 22-23 August 2014
}

School-based body image interventions for girls have typically been evaluated in single-sex rather than coeducational settings. However, there may be advantages to including boys within classes and it might also be more practical to deliver interventions to co-educational classes. Hence, it is important to examine any difference in outcomes between these two delivery settings. This study evaluated a six-session, co-educational version of the body image intervention, Happy Being Me. Participants were Year 7 girls from 5 schools randomly allocated to receive either the intervention in a single-sex setting $(n=74)$, co-educational setting $(n=73)$ or no intervention control $(n=53)$. Self-report questionnaires assessed body dissatisfaction, internalisation of media ideals, appearance comparisons, self-esteem, and depression at baseline, postintervention, and 6-month follow-up. Improvements were found in body dissatisfaction, internalisation, appearance comparisons, and self-esteem, from baseline to postintervention in the intervention groups compared with the control group. Intervention effects were maintained for internalisation, appearance comparisons, and self-esteem at 6-month follow-up. Baseline appearance conversations moderated body dissatisfaction outcomes. There were no significant differences in body image outcomes between single-sex or co-educational delivery formats. These findings provide further evidence of the efficacy of Happy Being Me and suggest that this intervention is equally valuable in single-sex or co-educational settings.

This abstract was presented in the Peter Beumont Young Investigator award finalist stream of the 2014 ANZAED Conference.

\footnotetext{
* Correspondence: candice.dunstan3@gmail.com

La Trobe University, Melbourne, Australia
}

(c) 2014 Dunstan et al; licensee BioMed Central Ltd. This is an Open Access article distributed under the terms of the Creative Commons Attribution License (http://creativecommons.org/licenses/by/4.0), which permits unrestricted use, distribution, and reproduction in any medium, provided the original work is properly cited. The Creative Commons Public Domain Dedication waiver (http://creativecommons.org/publicdomain/zero/1.0/) applies to the data made available in this article, unless otherwise stated.
Submit your next manuscript to BioMed Central and take full advantage of:

- Convenient online submission

- Thorough peer review

- No space constraints or color figure charges

- Immediate publication on acceptance

- Inclusion in PubMed, CAS, Scopus and Google Scholar

- Research which is freely available for redistribution
C Biomed Central 